\title{
Violence against Women in Eka Kurniawan's Vengeance Is Mine, All Others Pay Cash
}

\author{
Dian Febriyanti \\ Universitas Negeri Surabaya \\ e-mail: dfebriyanti66@gmail.com \\ Pratiwi Retnaningdyah \\ Universitas Negeri Surabaya \\ e-mail: pratiwiretnaningdyah@unesa.ac.id
}

\begin{abstract}
The aim of this article is to analyze the types of violence against women depicted in Eka Kurniawan's Vengeance Is Mine, All Others Pay Cash also to reveal the process of several female characters from being disempowered (after received violence by men) to empowering themselves. Those are global and common issues that society would face every day. This study uses thematic analysis on the basis of Gender-based Violence (GBV) to categorize the type of violence based on a theory of feminist by Beauvoir and also using Naila Kabeer's perspective to reveal that violence affect women in empower and disempower ways. The female characters that receive violence are Scarlet Blush, Iteung, Young Widow, and Jelita. The types of violence that occurred are sexual violence, physical violence, verbal violence, and psychological violence. However, the result of women's empowerment only causes Iteung itself, she is the only one who can survive and be empowered after fighting against patriarchal culture, while Scarlet Blush is the opposite.
\end{abstract}

Keywords: Gender-based Violence; Feminist Perspective; Women's Empowerment; Patriarchy

\section{Introduction}

Women are being treated as a second position in society because of their stereotype that they are powerless than men and this phenomenon could lead to some issues, such as domestic violence, highest rape, and harassment cases. In real life, people have commonly faced these issues and begin to start a movement, for example, Gender-Based Violence (GBV) against any gender especially to women by men. This term was first used in United Nations Declaration on 1993 by humanitarian community and mentioned as a kind of acts concerning the result in physical, sexual, mental harm and suffering to women also act of threatening, oppression, or arbitrary dispossession of freedom, whether happening in public or private life (SophieHamilton, 2014). The forms of violence committed by individuals are rape, domestic violence, sexual harassment, reproductive force, female mutilation, marriage by abduction, and forced marriage. According to the Merriam-Webster dictionary, violence is forcing someone to injure, destroy, damage, or abuse (Violence | Definition of Violence by Merriam-Webster, 2021). As in literature where the author of books are responsible to write anything they want to, people 
can easily found the problem about the violence that women received, especially from men. Many literary works are pictured the struggle of helpless women during their daily life, for example, The Color Purple by Alice Walker, the novel told about an American-African teenager named Celie who struggles hard living in Georgia. Celie often being violent by others, she wrote a letter to God about any bad things she received, for instance, about her father who raped her until she has to give birth.

This study analyzes the depiction of violence against women in Indonesian literary texts that setting up in 80s period, according to the interview of Eka Kurniawan as the author of the novel Vengeance Is Mine, All Others Pay Cash and Edwin as the director of adaptation movie of that book at JakCont 2020. This is another literary work that pictured violence against women bluntly as in the novel by Eka Kurniawan, entitled Vengeance Is Mine, All Others Pay Cash. The Indonesian version of this book-Seperti Dendam, Rindu Harus Dibayar Tuntaswas published in 2014 and was translated into English in 2017 by Anne Tucker. Most of Eka's books are represent authority or power and this can lead to a patriarchal culture where men hold the rules and raise women's disempowerment. Some of the literary works are reflected the cultural representation of certain genres and found it as a social problem such as violence against women. As mentioned above, a patriarchal society can cause the issue or this is a tool to expand in some privileged society. There are many kinds of violence that can be seen occurred to women. The ground of this case happened is because men still being dominant in the family and society too, while women are treated as second class because, again, of the stereotype or myth that said women are powerless and weak (M, 2016).

Regarding the phenomenon above, Vengeance Is Mine, All Others Pay Cash is worth analyzing because of its story, characters, and problems address issues. The patriarchal system is responsible for the issues that occurred women. How men pictured as the domination one to oppressed women are called patriarchy (Bere \& Arianto, 2019). This domination made men hold the rules of society in their beliefs, attitude, and views. According to Thompson (2002), the patriarchal system made women suppressed and stereotype because of their (man) power and sexuality. Women are overlooked since they are the subject of marginalization. Using a feminist perspective to analyzing the type of violence against women and find the causes of it so that the writer could develop into women's empowerment. Feminism is an outlook that seeks to highlight the cause of great damage by patriarchy upon women's lives. This movement aims to make equality between gender and giving legal protections for them. In this study, GenderBased Violence (GBV) will be used in analyzing each type of violence that occurred female characters in Vengeance Is Mine, All Others Pay Cash, and to examine the process of disempowering to empowering will be using Naila Kabeer's women's empowerment based on feminist perspective. Vengeance Is Mine, All Others Pay Cash has numerous issues that can be seen from any point of view. In general, the novel tells about the psychological problem of the main character Ajo Kawir who cannot get an erection because of trauma while watching a madman being raped in front of his eyes. During his life, he finds a lot of troubles too. His frustration made him want to fight with someone and it stated on the first page of the novel "Only guys who can't get hard fight with no fear of death." (Kurniawan, 2017). The journey begins after he needs to beat Mister Lebe, the one who forces Young Widow and it reminds 
him of his trauma. Another part is that several female characters received trauma through violence by men, those are: Scarlet Blush, a madman who gets raped by two policemen, second is Iteung, an Ajo Kawir's lover who has a complicated violence journey, and the third is Young Widow, the one who gets pressured by her landlord, and the last is Jelita who get verbally violence because of her physical appearance.

As mentioned in Beauvoir's Second Sex that feminism is used for analyzing the roles and position of women in aspects of life in the novel and also to solve the problems of this study (Beauvoir, 1989). This theory is used as a sharp knife for inequality that happened between women and men for over centuries and has been ignored, pushed aside, and underestimated by the patriarchal system (Bere and Arianto, 2019). Beauvoir stated that women have historically been treated as inferior and secondary to men for three reasons, first, to fulfill a male's needs and therefore exist to men, second, to follow external cues to seek validation of their worth, third, females have historically had far fewer legal rights, and therefore less public influence. The feminist perspective will focus on the gender inequality of patriarchal privilege and the primary cause of violence against women: the oppression of women (McPhail, Busch, Kulkarni, \& Rice, 2007). In the novel Vengeance Is Mine, All Others Pay Cash, the patriarchy system is well employed since Eka Kurniawan mentioned that most of his works are about masculinity, authority, and patriarchy culture during his interview with Vice on November $25^{\text {th }}, 2017$. Gender inequality in a patriarchal society is often pictured in having a lack of the same rights as an individual, women are being seen as powerless, the system is being controlled only by men, and many more. While women's empowerment could be thought of in the three terms of resources (pre-conditions), agency (process), and achievement (outcomes) (Kabeer, 1999).

There are several recent studies of violence against women that examines by scholars to reveal the complication of this issue and also to help the writer to find the newest understanding of violence against women. The three of those studies that using different perspective are: Domestic Violence against Women in Isinga: Roman Papua Novel by Dorothea Rosa Herliany by Reno Mardhatilah Sabrina and Yenni Hayati (2020); Symbolic Violence against Women in Indonesian Short Story 'Sepasang Mata Dinaya Yang Terpenjara' by Tomi Arianto (2018); and the last one is from Surbhi Malhotra, namely Tracing the forms of Violence against Gender in Patriarchal Society: A Study of Bapsi Sidhwa's The Pakistani Bride (2019). Those studies are using various approaches to problem-solving. In Indonesian literature, Sabrina and Hayati have written about violence as a form of discrimination against women and analyzing the various forms of violence such as physical, psychological, sexual abuse, and abandonment of the household and reveal that all forms of violence experienced by female characters are contained in Article 5 of Law No. 23 of 2004. Using the concept of existential feminism by Simone de Beauvoir to examine the articles, Sabrina and Hayati conclude that violence comes in the form of struggle from the character who had existential feminist thinking to become an intellectual. The contextualization of the struggle for extension feminism, although indirectly and still preserved patriarchal power is successfully showed in the novel (Sabrina \& Hayati, 2020). 
Unlike Sabrina and Hayati, Arianto is conducted to analyze the symbolic violence in 'Sepasang Mata Dinaya yang Terpenjara' using a theory of symbolism by Pierre Bourdieu and also used qualitative descriptive method for analysis. Tomi concludes that various problems in the analysis of 'Sepasang Mata' short story that related to the inequality of social culture between women and men in Balinese society have been formed in a structural and continuous culture that is rooted down to the smallest structure in the family (Arianto, 2018). Symbolic violence is portrayed in the short story are doing by some agents or characters who have more capital and dominance, such as the parents of Dinaya, her husband, and the people who apply the patriarchal culture. Tomi stated that Balinese women are received some acts of violence by society, and it is reflected as symbolic forms include: symbolic violence by parents, symbolic violence of the individual man, and symbolic violence in society (Arianto, 2018).

The feminist approach is commonly used in analyzing violence against women because it is related to the women's agency and mostly the reasons behind it, for instance, patriarchy. Similar to Sabrina and Hayati, Malhotra and its analysis were using a feminist approach, namely Tracing the Forms of Violence against Gender in Patriarchal Society: A Study of Bapsi Sidhwa's The Pakistani Bride is an attempt to portray the diverse troubles experienced by several female characters named Zaitoon, Carol, and Hamida who lived in a patriarchy society, Pakistani culture. In the final, Malhotra concludes that Sidhwa's work created the violence against gender by the patriarchal culture which is in contrast with feminism is revealed in the analysis, also Malhotra encourages the reader to get more achievement in his paper (Malhotra, 2019).

This paper describes the types of violence that women received from men using Gender-based Violence and Beauvoir's feminist perspective and also examines how violence affect women in different ways such as in hopeless and empower way. In analyzing the violence, there will be five types according to Newfoundland Labrador Canada (n.d.), including sexual violence, physical violence, verbal violence, emotional violence, and psychological violence.

\section{Method}

This article will employ a thematic analysis on the basis of Beauvoir's Second Sex, using theory of feminism. First the paper will examine the most common five types of violence in accordance with Gender-based Violence (GBV) in Newfoundland Labrador Canada (n.d.) article experienced by female characters, namely sexual violence, physical violence, verbal violence, emotional violence, and psychological violence. The female characters that received those kind of violence are Iteung, Scarlet Blush, Young Widow, and Jelita.

The analysis will then continue to examine how violence affect female characters in different ways; hopeless and empower. There are two characters namely Scarlet Blush and Iteung who find themselves in opposition to their destiny in life. Iteung, who can stand up and fight back some men in order to defend herself after being harassed by men have more privilege than the other character, Scarlet Blush who has mental health issue that cannot do anything to prevent nor defend herself from dangerous men, especially she lives alone after her husband died. This article shows several questions that must be tackled: How is violence against women 
depicted in Vengenace Is Mine, All Others Pay Cash? How does the violence affect female characters?

\section{Discussion \\ Sexual Violence}

In proportion to the novel, female characters that being sexual violence is quite much than the other type of violence and all of them are ended up being sexually violence, when the persons are forced to take a part in sexual activity, it called sexual violence. The first one is Scarlet Blush, a madman who has trouble experience with her deceased husband. This scene involves two policemen. The night when they go to the Scarlet Blush's house and raped her brutally. Eka Kurniawan elucidates this scene without mitigating any single taboo or rude words.

"Greedily, Scarface went back to licking Scarlet Blush's breasts, burying his face them while the woman thrashed about." (Kurniawan, 2017:25)

Scarlet Blush tries to run away but Scarface and the other one keep pull her out and raped her harshly and it is hard for her to let go when two men see her as their evening meal. Another sexual violence comes from a female character named Iteung. She is great at fighting because she joined a martial arts academy. Before she marries Ajo Kawir, her worst experience with her teacher begins in elementary school, namely Mr. Toto. He often asks Iteung to help him after the class end, to separating girl and boy's homework and that is how he takes benefit of her.

\footnotetext{
“But Mr. Toto's hands would already be inside Iteung's shirt, underneath her undershirt. Maybe those little mounds of hers only filled half of handful but they were solid and firm. Mr. Toyo's hands would fondle and squeeze them. Iteung would almost squeal, but she'd hold it in. Her pencil would fall from her trembling hand." (Kurniawan, 2017: 138)
}

She feels strange and rejects it but Mr. Toto keeps pushing her to do anything he wanted. This kind of thing makes Iteung get trauma and leads her to prevent herself from a predator or a bad guy like him. She starts joining arts martial academies and growing manly. She loves to fight and will brutality kill someone who in trouble with her.

Another female character that suffers from sexual violence is Young Widow. She cannot pay the rent to her landlord, Mister Lebe, but he can help her by one condition that she must accompany and sleep with him.

"Mister Lebe got on top of her, probing every curve and crevice of her body.

She kept on crying. Mister Lebe traced the outline of her lips, caressing her

neck and her ears. She wept." (Kurniawan, 2017:40)

Young Widow feeling depressed and pathetically sad. Especially when Mister Lebe knows that she gets pregnant and the folks are sneered at both of them. The story does not end there, Mister Lebe reports her to the court because she does not pay the rent and when she tries to defend herself, she has no pieces of evidence or witness to speak up. 


\section{Physical Violence}

Physical violence occurs when the persons use their part of body to control someone's actions. The night when Scarlet Blush being raped by two policemen, she also gets various physical violence on their bodies.

"Scarface approached Scarlett Blush and kicked her backside, barking, "Go take a bath!" Scarlet Blush didn't move and Scarface kicked her again, and again ordered, "Go take a bath!”." (Kurniawan, 2017:20)

This is cannot be done by any human, especially men to a woman who has a mental illness and cannot stand to her right. It also can be called as exploiting the unconscious women. Another quotation is:

"Shivering from the cold, the crazy woman tried to move away from the water, but Scarface shoved her body back into place with one kick. After holding her there with his boot for a few more moments, Scarface finally bent over and with nimble movements stripped Scarlet Brush of her clothes". (Kurniawan, 2017:21)

The text above represents the physical violence suffered by Scarlet Blush. Her response to that activity is not like how the readers expect. She lost her mind and will not be feeling ashamed, nor inferior but physically in pain.

\section{Verbal Violence}

Verbal violence occurs when the persons use language, whether it is spoken or written, to cause harm to someone. This scene happens when Ajo Kawir works as a truck driver and met Gaptooth Mono who soon to be his assistant. In their journey, they stopped and go and met a lot of people. And then they stopped in Gaptooth Mono's home area. Ajo Kawir leaves him a minute and Gaptooth Mono waits for him under a tree. Suddenly come Marwan and greet him. The scene where verbal violence happens is not be heard by the victim, Nina, who is Gaptooth Mono's neighbor and he falls in love with her. Marwan tells him that he will not get her or slept with her because she is sort of 'expensive', she will sleep with you if you give her some money, said Marwan to Gaptooth Mono.

"Nina. Nina. Nina! I slept with Nina. She's expensive but her hole's delicious, crazy." (Kurniawan, 2017:175)

On the other hand, Gaptooth Mono wants to punch Marwan in the face but discourages it. Even Nina does not know that some men talk bad behind her, it will hurt her.

Another female character is Scarlet Blush, she is not only got physical, sexual, but verbal violence too.

"She let out a little shriek and Scarface slapped her face yelling, "Shut up,

psycho!" (Kurniawan, 2017:24)

She receives much brutality violence and cannot protect herself because she had a mental illness. According to Paul Wallin, the most experienced and knowledgeable defense attorney in Southern California, whoever does an unconscious crime to a person, it still categorized as a crime and should be punished severely. A rude word that comes from the policemen's mouth is not valid, they shout 'psycho' to her while she unconsciously does not understand the situation. 


\section{Emotional Violence}

Emotional violence occurs when the persons say or do something to make someone worthless or dumb. This kind of violence is not going to leave scars in a body but has a huge impact on the inside, the victim's confidence, and self-esteem. In this novel, a woman who suffers emotional violence is Young Widow. She is about thirty-two years old having two kids, she rents a house from a guy in the fishpond business named Mister Lebe that soon to be the one who violence against her emotionally and sexually. The accident begin when Young Widow's husband died, two months after that, Mister Lebe come to her house to collect the rent, unfortunately, she does not have any money at that time and let him wait for some days. But then, Mister Leber offer something. He says that Young Widow does not have to pay the rent as long as she let him sleep with her. Young Widow does not say anything and does what he wants her to be.

"At first the Young Widow refused to service them, but her landlord threatened to drag her and the two children out of house and toss them in the street. She had no choice, so she received them all on her bed. The pain in her chest grew deeper and wider. She no longer cared about the other pain". (Kurniawan, 2017: 41)

Poor Young Widow. She really cannot do anything about that. But after a while, Mister Lebe begins to invite his friend, and then another day he invites more than one of his friends. It hit her, moreover, she gets pregnant and not knowing who the father of her baby.

In this scene, the pictured of authority or patriarchy in society is firm. To take advantage of the weakest one and not giving any response after what they have done is one of the examples of patriarchal culture.

\section{Psychological Violence}

Psychological violence involves when someone saying or doing a thing that makes someone feel bad or it occrurs when the persons use threats and causes fears to control other people. This violence will affect emotional or mental harm to the victim and might lead to depression and suicidal behavior. It may not hurt the body, but it can be just as painful and distressing in other ways. Scarlet Blush receives this kind of violence and it leads her to death. There is still speculation whether she died because she murdered or do suicide, but if it is a murder, there is no evidence to appear.

"And not long after that night, the people found Scarlet Blush dead in her own backyard. Lying there next to her husband's grave". (Kurniawan, 2017:27)

Psychological violence tends to hurt more and leave an invisible big wound to the victim, same as verbal and emotional violence that is a part of psychological. According to AlModallal (2012), psychological violence is responsible for increasing the risk of mental illness. In the novel, Scarlet Blush is a madman who lives alone after the death of her husband and then gets raped by two policemen, that brutality managed to cause her death.

\section{Violence Experienced Lead to Women's Empower and Disempower}

Empowerment has been defined as a process of increasing the capacity of individuals or groups to make choices and to transform those choices into desired actions and outcomes 
(Julia, 2007). The writer made it clearer by defined women's empowerment as a process to control their lives as free individuals after being disempowered. According to Mandal (2013), there are five sectors of empowerment, those are social, educational, economic, political, and psychological. In this article, there is one female character that successfully being empowerment in the novel Vengeance Is Mine, All Others Pay Cash was Iteung. As stated above that it must be being disempowered or suffer first to be empowered or authorize, Iteung, is the compatible example of women's empowerment term.

"And that afternoon, they fought. Iteung had clearly mastered the martial arts.

Despite her delicate looks, she was very strong and had good stamina. Ajo

Kawir took hit after solid hit, and he had to admit to himself that her

powerful blows hurt more than the man punches most men threw."

(Kurniawan, 2017:44)

In a patriarchal society where women are taking place in second places and not being published of their capability in overcoming the difficulty make a male character-Ajo Kawir--amazed at what Iteung has done to him. This could be an achievement of women's empowerment after hidden away for a long time, also a validation of what women as an individual are having power and sometimes it could be stronger than men.

"He almost touched the girl, ready to engulf her body, but Iteung moved much quicker. One hand kick landed right on his balls. Mr. Toto shrieked, but his shriek didn't get all the way out because another blow slammed into his jaw, and then more kicks and punches came. He couldn't escape. In just a few moments, the man collapsed next to the chair legs, with a swollen nose and blood in the hand clutching at his balls. Sprawled out unconscious. The girl calmly collected her clothes and put them back on. After gathering up Mr. Toto's clothes as well, she left." (Kurniawan, 2017:148)

This part happened after Iteung studied martial arts and take revenge on her former teacher. Iteung once a victim of sexual harassment that has been done by her former teacher, she felt trembled and pain between her two legs after that. Those pain are last, it proves at the beginning of the conversation that she hasn't come to see him since she changed school and amazed that she all grown up (Kurniawan, 2017:147), so it looks like a long time ago. A woman who survived from being the victim of sexual harassment might be a kind of strong woman because a lot of things could happen to them such as; being stressed, trauma, having suicide feeling, feeling low of herself, and many more. The coping mechanism of a woman that experienced those is developing to maintain her own emotions. She chooses to join martial art and take revenge on a thing she felt wrong rather than down in the dumps.

"The policeman at the security post was shocked to see a woman, her hands covered in blood, walking toward him. Now she was standing right in front of him. "Mr. Policeman, I killed someone." The policeman stood frozen" (Kurniawan, 2017:204)

Most of the women's empowerment in the novel is about a woman fighting man, and it could be used as a symbol of opposition toward patriarchal culture and gender equity in the term of 
women's empowerment. Again, Iteung were shocking men with her bravery, especially she is typical of a nothing-to-lose kind of woman. In patriarchal culture, women must be powerless, being shut, and get no same rights as well, everything must be according to men and sometimes it gives a negative impact to the men too, for example; men must be masculine and never have to wear pink stuff or society will mocking them cause it's only acceptable for women. The gap between male and female characters in the novel Vengeance Is Mine, All Others Pay Cash is well visualized, especially to the female characters like Scarlet Blush and Iteung.

Violence against women affect some female character's life differently, from passage above, Iteung is the one who can survive and being empower, while in the other side there is Scarlet Blush, who cannot do anything to defend herself because of some limitations that she has. Iteung is privileged enough to take Martial Arts Academy and having parents that support her dreams, while Scarlet Blush is struggling with the grief of her husband and also being a victim of sexual harassment. The chaos in Scarlet Blush's life start after she knowing that her husband died, many speculation appear and she cannot justify it because she is not in a good mental condition.

\section{"The kids knew Scarlet Blush was a madwoman who often went berserk.}

None of them had actually ever seen one of her house alone, refusing to talk

to anyone but sometimes laughing to herself, or shrieking for no reason."

(Kurniawan, 2017:12)

People know that Scarlet Blush has mental issues but some of them are take an advantages from it, for example two policemen who raped her brutally. In the previous discussion, it clearly explain that Scarlet Blush is the one who received more than one types of violence. Two things that women must have to reach empowerment are resource and access and Scarlet Blush don't even have one from them. Resource is defined as the potential that person must have and access is kind of achievement in order to being empower (Kabeer, 1999). What makes Scarlet Blush and Iteung received different society point of view is that Scarlet Blush often do something that normal people will not do.

"It was said that people once came from the social welfare office and tried to take her away, but she went nuts and bit one of them-no one could be sure whether that had actually happened, but no one ever tried to move her from her house again." (Kurniawan, 2017:12)

No one know what happened to Scarlet Blush' last day before she died, but it's not long after she being raped and harrased by two policemen. There are some speculation arise, whether she do suicide because she cannot bear the burden of trauma or she been killed with policemen's wife who knows about their husband's activity.

\section{Conclusion}

The struggle of female characters in the novel is pictured how patriarchal culture is dangerous for both gender and would be getting worse for women to live a life because there will be no safe places to take cover but themselves. Gender-based Violence (GBV) is one example of manpower, it happened because violence against women is increasing. No matter how small or big the act of violence, it still give an impact and creates trauma to the victim. 
The effect of violence could lead to suicide speculation on Scarlet Blush, low self-esteem to Young Widow, and trauma on Iteung. Violence against women affect several female characters in different ways. There is only one female character in the novel Vengeance Is Mine, All Others Pay Cash survived because of the trauma that made her need to take revenge on men that harasses her, and a hankering to take care of herself, she is Iteung, but there is also Scarlet Blush who get the opposite and sadly she cannot defend herself because she is a crazy. The feminist perspective seeks equity for both gender and attempts to eliminate stereotyping of women, as a result, Iteung's reaction to her experience could represent feminism. While women's empowerment in the novel is mostly referred to as the duels of women and men or Iteung against Ajo Kawir, Good Budi, and Mr. Toto, and she won. They saluted her after her capability for being unbeatable or hard to lose.

\section{References:}

Al-Modallal, H. (2012). Psychological partner violence and women's vulnerability to depression, stress, and anxiety. International Journal of Mental Health Nursing, 21(6), 560-566. https://doi.org/10.1111/j.1447-0349.2012.00826.x

Arianto, T. (2018). Symbolic Violence Against Women in Sepasang Mata Dinaya Yang Terpenjara Short Story By Ni Komang Ariani. KREDO : Jurnal Ilmiah Bahasa Dan Sastra, 2(1), 53-64. https://doi.org/10.24176/kredo.v2i1.2526

Beauvoir, S. de. (1989). The Second Sex. New York: Vintage Books.

Bere, N. O., \& Arianto, T. (2019). Woman Violence and Resistance in "Sweat" Short Story By Zora Neale Hurston: Feminist Approach. Jurnal Basis, 6(2), 249. https://doi.org/10.33884/basisupb.v6i2.1425

Kabeer, N. (1999). Resources, Agency, Achievements: Reflections on the Measurement of Women's Empowerment. 30(May), 435-464.

Kurniawan, E. (2017). Vengeance Is Mine, All Others Pay Cash (A. Tucker, ed.). London: Pushkin Press.

M, S. S. (2016). The Myth Women are Physically and Mentally Weak. Bio Pharma Research [Special issue]. Research \& Reviews: Journal of Hospital and Clinical Pharmacy.1. 96-102.

Malhotra, S. (2019). Tracing The Forms of Violence Against Gender in Patriarchal Society : A Study of Bapsi Sidhwa's The Pakistani Bride. IJCIRAS. 2(1), 75-76.

Mandal, K. C. (2013). Concept and Types of Women Empowerment. International Forum of Teaching and Studies, 9(2), 17-30.

Retrieved from http://www.joe.org/joe/1999october/comm1.php

McPhail, B. A., Busch, N. B., Kulkarni, S., \& Rice, G. (2007). An integrative feminist model: The evolving feminist perspective on intimate partner violence. Violence Against Women, 13(8), 817-841. https://doi.org/10.1177/1077801207302039

Merriam-Webster. (n.d.). Violence. In Merriam-Webster.com dictionary. Retrieved from https://www.merriam-webster.com/dictionary/violence

Newfoundland Labrador Canada. (n.d.) Retrieved from https://www.gov.nl.ca/vpi/about 
Febriyanti \& Retnaningdyah

Tell : Teaching of English Language and Literature Journal

Vol. 9, No.2, September 2021, Doi: http://dx.doi.org/10.30651/tell.v9i2.8272

/facts-about-violence/

Read-Hamilton, Sophie. (2014). Gender-based violence: a confused and contested term.

Humanitarian Practice Network. Retrieved January 13, 2021, from https://odihpn.org/magazine/gender-based-violence-a-confused-and-contestedterm/

Sabrina, R. M., \& Hayati, Y. (2020). Domestic Violence Against Women in Isinga : Roman Papua Novel by Dorothea Rosa Herliany. Proceedings of the $3^{\text {rd }}$ International Conference on Language, Literature, and Education (ICLLE), 174-178. https://doi.org/10.2991/assehr.k.201109.029

Thompson, T. L. (2002). The Historicity of the Patriarchal Narratives: The Quest for the Historical Abraham (reprint). New York: Bloomsbury Academic.

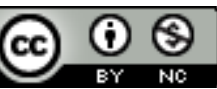

